\title{
Effect of a Newly Developed Pelleted Papermill Biosolids on Crop and Soil
}

\author{
Morteza Mozaffari*, Hannah C. Hays \\ Northeast Research and Extension Center Keiser, Department of Crop Soil and Environmental Science, \\ Division of Agriculture University of Arkansas System, Arkansas, USA \\ Email: *mmozaff@uark.edu
}

How to cite this paper: Mozaffari, M. and Hays, H.C. (2020) Effect of a Newly Developed Pelleted Papermill Biosolids on Crop and Soil. Journal of Agricultural Chemistry and Environment, 9, 1-12.

https://doi.org/10.4236/jacen.2020.91001

Received: November 17, 2019

Accepted: December 15, 2019

Published: December 18, 2019

Copyright $\odot 2020$ by author(s) and Scientific Research Publishing Inc. This work is licensed under the Creative Commons Attribution International License (CC BY 4.0).

http://creativecommons.org/licenses/by/4.0/

(c) (i) Open Access

\begin{abstract}
The US is one of the leading global producers of paper industry with approximately 24 percent of the share of world paper supply. Despite diversity of the feedstock and production methods, $\mathrm{C}$ rich papermill biosolids (PB) is a major byproduct of paper production process. Landfilling is the predominant method of PB management. Increasing landfill cost and its potential environmental consequences have incentivized research and development efforts to find beneficial uses for PB. This sensible option reduces the overall paper production costs and increases environmental sustainability. Pelletization of PB increases its marketability by reducing transportation costs. This greenhouse study was conducted to gain a better understanding of the properties and effects of a recently developed pelletized papermill biosolids (PPB) on bell pepper (Capsicum annuum L.) and soil. Urea and PPB were each applied at four total $\mathrm{N}$ rates equivalent to $45,90,135$, and $180 \mathrm{~kg} \mathrm{~N} \mathrm{ha}^{-1}$ and an additional control treatments of $0 \mathrm{~N}$ was included. The total $\mathrm{C}$ and $\mathrm{N}$ concentration in this PPB were 379 and $14 \mathrm{~g} \cdot \mathrm{kg}^{-1}$ respectively and its C:N ratio was 27.2. Nitrogen treatment significantly $(P \leq 0.0839)$ influenced pepper height, dry biomass, $\mathrm{N}$ concentration, and $\mathrm{N}$ uptake. Plant height ranged from 31.2 to $44.4 \mathrm{~cm} ; 135 \mathrm{~kg} \cdot \mathrm{ha}^{-1}$ urea-N and PPB-N produced the tallest and shortest plants respectively. Dry biomass of the pepper that did not receive any N, those treated with urea-N or PPB-N were 5.3, 5.7 - 7.5, and 5.9 - 6.5 g.plant ${ }^{-1}$ respectively. Nitrogen concentration in control treatment $(0 \mathrm{~N})$ was 36.4 $\mathrm{g} \cdot \mathrm{kg}^{-1}$ and that of pepper treated with any $\mathrm{N}$ ranged from $32.0-40.7 \mathrm{~g} \cdot \mathrm{kg}^{-1}$. There was an inverse numerical, albeit not always statistically significant, relationship between PPB rate and plant N concentration. Generally, pepper treated with urea removed significantly more $\mathrm{N}$ from soil than control or PPB treated pepper. Nitrogen uptake by plants that did not receive any $\mathrm{N}$ and those amended with urea or PPB were 194, 229 - 270, and 155 - 164 mg.plant ${ }^{-1}$ respectively. Pepper $\mathrm{N}$ uptake and concentration data indicate that
\end{abstract}


higher rates of $\mathrm{PPB}$ resulted in immobilization of native soil and PPB-N due to its wide C:N ratio (27.2). Nitrogen treatment significantly influenced soil $\mathrm{pH}$, SOM, total $\mathrm{C}$ and $\mathrm{N}(P>0.1)$. Soil organic matter and total $\mathrm{C}$ in post-harvest soil samples were $17.4-19.4$ and $21.9-35.0 \mathrm{~g} \cdot \mathrm{kg}^{-1}$ respectively. The observed increase in soil total $\mathrm{C}$ and SOM highlights the potential beneficial use of $\mathrm{PPB}$ as a means to improve soil health and sequester $\mathrm{C}$ in soil. Narrowing the C:N ratio of PPB, by coapplication or incorporation of the mineral $\mathrm{N}$ into the pellets will make it an attractive organic $\mathrm{N}$ fertilizer.

\section{Keywords}

Pelleted Papermill Biosolids, Pepper, Nitrogen, Urea, Beneficial Use

\section{Introduction}

The US paper industry produces more than $24 \%$ of the world paper using several chemical and mechanical methods for production of paper from pulp [1]. Regardless of the production method, biosolids is a major byproduct of paper production. Approximately 5.5 million Mg of dry papermill biosolids (PB) is produced by the US pulp and paper industry [2]. Traditionally landfilling has been the most widely used method of PB management. The increasing costs and environmental concerns about this practice have necessitated research and development efforts to find a more sustainable solution for PB management. Papermill biosolids is a mixture of organic compounds such as lignin, cellulose, hemicellulose and secondary treated PB contains $\mathrm{N}, \mathrm{P}$ and additional nutrients. In recent decades beneficial utilization of $\mathrm{PB}$ as a soil amendment has emerged as a sensible alternative to landfilling. A median $\mathrm{N}$ and $\mathrm{P}$ values of 23.3 and $4.2 \mathrm{~g} \mathrm{~kg}^{-1}$ respectively were reported for a secondary treated PB Camberato et al. (1997) [3], Camberato et al. (2006) [4]. The organic C, total N, and total P content of another secondary treated $\mathrm{PB}$ were $238,26.7$, and $15.3 \mathrm{~g} \cdot \mathrm{kg}^{-1}$ respectively Price et al. (2007) [5]. These results demonstrate that plant nutrients (N, P) and organic matter content of $\mathrm{PB}$ is determined by the feedstock, paper production method and biosolids treatment process, thus they can be quite variable. This variability indicates that each specific type of PB should be evaluated and utilized based on its effect on soil plant system to ensure a successful beneficial use program.

The effect of various $\mathrm{PB}$ on crop and soil has been investigated in field and greenhouse studies with a variety of crops. Application of $100 \mathrm{Mg} \cdot \mathrm{ha}^{-1} \mathrm{~PB}$ with a C:N of 86 reduced barley (Hordem vulgare L.) yield as compared to non-amended plants Aitken et al. (1998) [6]. Grain yield and N use efficiency of corn (Zea Mays L.) treated with $150 \mathrm{~kg}$ total $\mathrm{N} \mathrm{ha}^{-1}$ from two PBs with C:N ratio of 13 and 50 were 11.9 and $6.9 \mathrm{Mg} \cdot \mathrm{ha}^{-1}$ and $12 \%$ to $22 \%$ respectively $(P \leq 0.001)$ Gagnon et al. (2012) [2]. According to Vagstad et al. (2001) [7] application of $10 \mathrm{Mg}$ PB $\mathrm{ha}^{-1}$ with C:N ratio of about 30 or more tended to decrease barley grain yield. Application of a PB with C:N ratio of 14 increased the yield and $\mathrm{N}$ uptake of 
barley while application of another PB with C: $\mathrm{N}$ ratio of 31 did not influence the dry bean (Phaseolus vulgare L.) yield Ziadi et al. (2013) [8]. They also reported that anion exchange extractable soil $\mathrm{NO}_{3}-\mathrm{N}$ was decreased by application of a deinking $\mathrm{PB}$ with $\mathrm{C}: \mathrm{N}$ ratio of 65 ( $\mathrm{N}$-immobilization) and increased with application of a combined (primary and secondary treated) PB with C:N ratio of 14 [8]. Net $\mathrm{N}$ mineralization in an Entisol amended with $10 \mathrm{Mg} \cdot \mathrm{ha}^{-1}$ of a PB (C:N = 15.5) was not significantly more than that of the non-amended soil San Martin et al. (2016) [9]. In general application of $\mathrm{PB}$ with wide C:N ratio had increased $\mathrm{N}$ immobilization but application of $\mathrm{PB}$ with low C:N ratio had increased soil inorganic N Nunes et al. (2008) [10], Cabral et al. (1993) [11]. These outcomes indicate that the $\mathrm{C}: \mathrm{N}$ ratio of the $\mathrm{PB}$ is a major determinant of the crop response to $\mathrm{PB}$ application. Most researchers have suggested that a C:N > 30 will negatively impact crop yield potential and some have even reported a critical C:N ratio of 20 - 30 Cordovil et al. (2007) [12], Sims (1990) [13].

Amending soil with $\mathrm{PB}$ increased soil $\mathrm{C}$ and thus organic matter and the magnitude of the increase was dependent on $\mathrm{PB}$ composition and application rate [4] [14] [15]. For example amending a soil with 40, 80, and $120 \mathrm{Mg} \cdot \mathrm{ha}^{-1}$ of secondary treated $\mathrm{PB}$ increased the soil organic $\mathrm{C}$ by $0.4,0.6$, and $1.3 \mathrm{~g} \cdot \mathrm{kg}^{-1} \mathrm{re}-$ spectively [10]. These studies clearly demonstrate that soil and plant response to PB depends on several factors including its chemical properties (a function of production methods), application rate, and crop grown. Thus a successful beneficial use program requires information on crop and soil response to PPB when it is applied at agronomically reasonable rates.

Only a small percentage of total amount of PB produced in the US is currently utilized as a beneficial soil amendment, despite environmental and economic benefits of this sustainable practice. Widespread beneficial use of PB has been hampered by its high moisture content and bulky nature which increases the cost of long-distance transport and the need for specialized field application equipment. Pelletization (by heat and pressure) of biosolids will help to overcome these obstacles. Cooperative efforts in the US have led to successful development of a new pelleted papermill biosolids (PPB) which is a mixture of $\mathrm{PB}$ and a byproduct of cow manure. This newly developed PPB is currently at testing stage of product development. The objectives of this research were to measure and compare the effects of several rates of $\mathrm{PPB}$, urea, and a $0 \mathrm{~N}$ control on pepper: 1) plant height; 2) $\mathrm{N}$ concentration and uptake; 3) selected soil properties.

\section{Experimental Procedures}

A replicated greenhouse experiment was conducted at the University of Arkansas Northeast Research and Extension Center (NEREC) in Keiser Arkansas in 2017 (N: $35.674988^{\circ}, \mathrm{W}:-90.084732^{\circ}$ ). We evaluated pepper and soil response to urea and $\mathrm{PPB}$ each applied at four total $\mathrm{N}$ rates equivalent to $45,90,135$, and $180 \mathrm{~kg}$ total $\mathrm{N} \mathrm{ha}^{-1}$. The PPB applications rates were approximately equivalent to $2.24,4.48,6.72$, and $8.48 \mathrm{Mg} \mathrm{ha}^{-1}$ on as is basis. A control treatment of $0 \mathrm{~N}$ was 
also included. Detailed experimental treatments are listed in Table 1. Experimental design was a randomized complete block and each treatment was replicated five times.

\section{Greenhouse Cropping:}

A bulk sample of the $0-15 \mathrm{~cm}$ depth of a soil mapped as Deerfield loamy fine sand (mixed, mesic Aquic Udipsamments) was collected, dried to constant moisture in a forced-air oven at $40^{\circ} \mathrm{C}$, and ground to pass a 2-mm sieve. Dried soil sample was thoroughly mixed in a new cement mixer. Soil texture was measured by the hydrometer method [16]. Soil $\mathrm{pH}$ was measured by 1:1 soil: water [17] and soil organic matter (SOM) was measured gravimetrically by loss on ignition (LOI) [18]. Soil total carbon (C) and $\mathrm{N}$ were measured by combustion using an Elementar Variomax instrument [19]. Soil $\mathrm{NO}_{3}-\mathrm{N}$ and $\mathrm{NH}_{4}-\mathrm{N}$ were extracted by $2-\mathrm{M} \mathrm{KCl}$ and measured on a Skalar auto analyzer [20]. Those two are the inorganic sources of soil $\mathrm{N}$ which are taken up by plants. Mehlich-3 extractable nutrients were measured by the standard procedure [21]. The PPB was ground to fineness in a new coffee grinder and analyzed for $\mathrm{pH}$, total $\mathrm{C}, \mathrm{N}$, $\mathrm{NO}_{3}-\mathrm{N}$ and $\mathrm{NH}_{4}-\mathrm{N}$ as mentioned before. Total $\mathrm{P}$ and $\mathrm{K}$ in the PPB were measured as outlined by Peters [22].

We amended the bulk soil sample with monocalcium phosphate $\left(\left(\mathrm{CaH}_{2} \mathrm{PO}_{4}\right)_{2}\right)$, potassium chloride $(\mathrm{KCl})$, sulfate of potash and magnesia (Sul-Po-Mag), zinc sulfate $\left(\mathrm{ZnSO}_{4}\right)$ and pelletized lime to supply the equivalent of $56,112,36,48$, 8.4, and $2800 \mathrm{~kg} \cdot \mathrm{ha}^{-1}$ of: $\mathrm{P}_{2} \mathrm{O}_{5}, \mathrm{~K}_{2} \mathrm{O}, \mathrm{Mg}, \mathrm{S}, \mathrm{Zn}$, and lime respectively. This ensured that $\mathrm{N}$ was the only soil amendment that could limit pepper yield potential.

The experimental units consisted of $24-\mathrm{cm}$ diameter-7.2-liter black plastic pots. The required amount of $\mathrm{N}$-treatment for all five replications of each treatment was thoroughly mixed with the appropriate quantity of soil in a cement

Table 1. Nitrogen sources, total $\mathrm{N}$ application rates, and eight $\mathrm{N}$-treatments for a pepper experiment conducted in a greenhouse at the University of Arkansas Northeast Research and Extension Center in Keiser, Arkansas in 2017.

\begin{tabular}{cccc}
\hline N source & Amendment rate & Total N rate & N-treatment \\
\hline None & 0 & $\mathrm{~kg} \mathrm{~N} \mathrm{ha}^{-1}$ & \\
Urea & 98 & 0 & none \\
Urea & 195 & 45 & Urea-45 \\
Urea & 292 & 90 & Urea-90 \\
Urea & 382 & 135 & Urea-135 \\
PPB & 2240 & 180 & Urea-180 \\
PPB & 4480 & 45 & PPB-45 \\
PPB & 6720 & 90 & PPB-90 \\
PPB & 8480 & 135 & PPB-135 \\
\hline
\end{tabular}


mixer. Then $9 \mathrm{~kg}$ of $\mathrm{N}$-treated soil was transferred from cement mixer into each plastic pot and the pot was tamped three times to create a uniform soil bulk density. Five seeds of a bell pepper Hybrid "Alliance F1" were planted in each pot on 5-July 2017 and thinned to one seedling per pot five days after germination. Pepper was grown for 89 days. Greenhouse temperature was set to maintain at $24^{\circ} \mathrm{C}$. Supplemental light was provided $12 \mathrm{hrs}^{- \text {day }^{-1}}$ from 7:00 am to 7:00 pm and pepper was watered as needed. Pepper was grown for 77 days and harvested on 3-October 2017.

\section{Post-harvest Pepper and Soil Sample Collection and Analysis}

At the end of the study, we measured and recorded the height of each pepper plant from the lowest node above the soil level to the top of the apical meristem, then cut the total above-ground portion of each plant at $1 \mathrm{~cm}$ above the soil level. Plant samples were dried to constant weight in a forced-air oven and their dry biomass was recorded. Plant samples, from all five replications, were ground in a Willey Mini-Mill to pass a 20-mesh sieve and analyzed for total N with combustion method [19]. Total $\mathrm{N}$ uptake per plant was calculated by multiplying the whole plant dry biomass by its respective $\mathrm{N}$ concentration.

After pepper harvest we transferred the soil from each pot (selected $\mathrm{N}$-treatments, 0,90 and $180 \mathrm{~kg}$ total $\mathrm{N} \mathrm{ha}^{-1}$ ) to a clean plastic tub, removed the roots manually, mixed the soil thoroughly, and collected representative samples by the quarter method. Postharvest soil samples were dried as described, ground to pass a $2-\mathrm{mm}$-sieve and analyzed for $\mathrm{pH}$, total $\mathrm{N}, \mathrm{NH}_{4}-\mathrm{N}, \mathrm{NO}_{3}-\mathrm{N}$, and $\mathrm{SOM}$ as described above.

\section{Statistical Analysis}

The effect of N-treatment on pepper growth parameters and selected soil properties were evaluated by analysis of variance using the SAS software package. When appropriate, means were separated by the least significant difference (LSD) method and interpreted as significant when $P \leq 0.10$.

\section{Results and Discussion}

\section{Characterization of Soil and PPB}

Analysis of the pre-amendment soil indicated that the soil texture was sandy loam where sand and clay were the most and least predominant soil particles respectively. Soil $\mathrm{pH}$ was 5.5, SOM, total $\mathrm{C}$ and $\mathrm{N}$ were $28,12.4$ and $0.64 \mathrm{~g} \cdot \mathrm{kg}^{-1}$ respectively (Table 2). Soil inorganic $\mathrm{N}$ was low $\left(13.2 \mathrm{mg} \cdot \mathrm{kg}^{-1}\right.$ ) and was predominated by $\mathrm{NH}_{4}-\mathrm{N}$. Mehlich-3 extractable $\mathrm{K}$ was $28 \mathrm{mg} \cdot \mathrm{kg}^{-1}$ indicating the need for supplemental $\mathrm{K}$ fertilization.

The $\mathrm{pH}$ of $\mathrm{PPB}$ was 7.7 and was within the range of values reported by other $\mathrm{PB}$ researchers [5] [8] [23] [24] [25]. Total C and $\mathrm{N}$ concentrations were 379 and $14 \mathrm{~g} \cdot \mathrm{kg}^{-1}$ respectively and the C:N ratio was 27.2 (Table 3). Concentration of total $\mathrm{C}$ and $\mathrm{N}$ in a mixed pelleted biosolids was 260 and $16.8 \mathrm{~g} \cdot \mathrm{kg}^{-1}$ respectively [9] [5]. Total $\mathrm{C}$ and total $\mathrm{N}$ concentrations of 256 and $3.0 \mathrm{~g} \cdot \mathrm{kg}^{-1}$ respectively were reported for a PB sample from a Papermill in Canada [5]. Total C and N 
Table 2. Selected mean $(n=2)$ chemical properties of the thoroughly mixed untreated bulk soil sample of the surface horizon of a Deerfield loamy fine sand that was used in the greenhouse study with pepper at the University of Arkansas Northeast Research and Extension Center, in Keiser, Arkansas in 2017.

\begin{tabular}{|c|c|c|c|c|c|c|c|c|c|c|c|c|}
\hline \multirow[t]{2}{*}{ Soil pH } & \multirow{2}{*}{ Sand } & \multirow{2}{*}{ Silt } & \multirow{2}{*}{ Clay } & \multirow{2}{*}{$\begin{array}{l}\text { Soil Organic } \\
\text { Matter }\end{array}$} & \multirow{2}{*}{ Total C } & \multirow{2}{*}{ Total N } & \multirow{2}{*}{$\mathrm{NO}_{3}-\mathrm{N}$} & \multirow{2}{*}{$\mathrm{NH}_{4}-\mathrm{N}$} & \multicolumn{4}{|c|}{ Mehlich-3-extractable nutrients } \\
\hline & & & & & & & & & $\mathrm{P}$ & $\mathrm{K}$ & $\mathrm{Ca}$ & $\mathrm{Mg}$ \\
\hline & ----- & ---- & ---- & $-\mathrm{g} \cdot \mathrm{kg}^{-1}=-$ & ------ & ------- & ------ & ------ & $-\mathrm{ms}_{\mathrm{s}}$ & --- & $---\cdot$ & ---- \\
\hline 5.5 & 630 & 300 & 70 & 28 & 12.42 & 0.64 & 1.52 & 11.70 & 75 & 28 & 176 & 25 \\
\hline
\end{tabular}

Table 3. Selected mean properties of the finely ground sample of the pelletized Papermill biosolids (PPB) that was used in a greenhouse study with pepper at the University of Arkansas Northeast Research and Extension Center in Keiser, Arkansas in 2017.

\begin{tabular}{cccccccc}
\hline Test Material & $\mathrm{pH}$ & Total C & Total N & $\mathrm{C} / \mathrm{N}$ ratio & $\mathrm{NH}_{4}-\mathrm{N}$ & $\mathrm{P}_{2} \mathrm{O}_{5}$ & $\mathrm{~K}_{2} \mathrm{O}$ \\
\hline Pelletized Papermill biosolids (PPB) & 7.7 & 378.7 & 13.9 & 272 & 0.18 & 5.0 & 6.8 \\
\hline
\end{tabular}

concentrations of 276 and $3 \mathrm{mg} \cdot \mathrm{kg}^{-1}$ and C:N of 92 respectively have been reported for another PB [10]. Total C and N concentration range of $329-438$ and $10.5-31.5 \mathrm{~g} \cdot \mathrm{kg}^{-1}$ respectively were reported for two combined PB [8].

The $\mathrm{C}$ and $\mathrm{N}$ concentration of this newly developed PPB suggest its potential as an organic source of $\mathrm{N}$. Nitrate-N was below the detection limit and $\mathrm{NH}_{4}-\mathrm{N}$ was very low $\left(0.18 \mathrm{~g} \cdot \mathrm{kg}^{-1}\right)$ therefore organic $\mathrm{N}$ was the predominant source of $\mathrm{N}$. This is in agreement with others including Gagnon et al. (2012) [2] who reported that only $1 \%$ of total $\mathrm{N}$ in a combined $\mathrm{PB}$ was in $\mathrm{NH}_{4}-\mathrm{N}$. The $\mathrm{C}: \mathrm{N}$ ratio and low inorganic $\mathrm{N}$ content of this $\mathrm{PPB}$ suggested that $\mathrm{N}$ mineralization/immobilization was the key decisive factor in determining its $\mathrm{N}$ supplying capacity. The PPB contained several other plant essential nutrients including P and $\mathrm{K}$, thus it is a potential high organic matter low grade source of those two nutrients.

\section{Pepper Response to N-treatment}

Pepper dry biomass, $\mathrm{N}$ concentration, and $\mathrm{N}$ uptake were significantly ( $\mathrm{P} \leq$ 0.0839 ) influenced by $\mathrm{N}$-treatment (Table 4). Plant height ranged from 31.2 to $44.4 \mathrm{~cm}$ where $135 \mathrm{~kg} \mathrm{ha}^{-1}$ of urea-N and PPB-N produced the tallest and shortest plants respectively. Dry biomass of the peppers that did not receive any $\mathrm{N}$, those treated with urea-N or PPB-N were 5.3, 5.7 - 7.5, and 5.9 - 6.5 g.plant ${ }^{-1}$ respectively. Pepper that did not receive any $\mathrm{N}$ and that treated with $45 \mathrm{~kg}$ urea-N $\mathrm{ha}^{-1}$ produced the numerically smallest and largest plant dry biomass (5.3 vs 7.5 g.plant ${ }^{-1}$ ). This numerical trend is consistent with Gagnon et al., (2012) [2] who

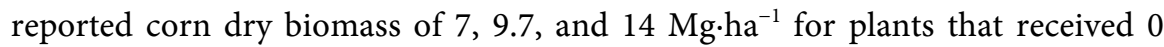
and $150 \mathrm{~kg} \mathrm{~N} \mathrm{ha}^{-1}$ from $\mathrm{PB}$ and mineral $\mathrm{N}$ fertilizer respectively. Pepper fertilized with $180 \mathrm{~kg}$ urea- $\mathrm{N} \mathrm{ha}^{-1}$ appeared dark green and produced significantly smaller dry biomass than plants treated with $45 \mathrm{~kg}$ urea-N ha ${ }^{-1}$ reflecting excessive $\mathrm{N}$ supplied by that higher $\mathrm{N}$-rate. Pepper amended with high PPB rates exhibited visual symptoms consistent with $\mathrm{N}$ deficiency (yellowing of the lower leaves). 
Table 4. Pepper plant height, whole plant dry biomass, $\mathrm{N}$ concentration and total $\mathrm{N}$ uptake as affected by $\mathrm{N}$-treatment from urea and pelletized Papermill biosolids (PPB) in a greenhouse study conducted at the University of Arkansas Northeast Research and Extension Center in Keiser, Arkansas in 2017.

\begin{tabular}{|c|c|c|c|c|c|c|}
\hline $\mathrm{N}$ source & Total N-rate & $\mathrm{N}$-treatment & Plant height & Plant dry biomass & $\mathrm{N}$ concentration & $\mathrm{N}$ uptake \\
\hline & $\mathrm{kg} \cdot \mathrm{ha}^{-1}$ & & $\mathrm{~cm}$ & g.plant ${ }^{-1}$ & ---- g. $\mathrm{kg}^{-1}----$ & $\mathrm{mg} \mathrm{N}$ plant $^{-1}$ \\
\hline None & 0 & none & $35.3 b c^{2}$ & $5.3 \mathrm{c}$ & $36.4 \mathrm{ab}$ & 194cde \\
\hline Urea & 45 & Urea-45 & $37.2 \mathrm{~b}$ & $7.5 \mathrm{a}$ & $36.2 \mathrm{bc}$ & $270 \mathrm{a}$ \\
\hline Urea & 90 & Urea-90 & $35.3 \mathrm{bc}$ & $6.1 b c$ & $40.7 \mathrm{a}$ & $249 \mathrm{ab}$ \\
\hline Urea & 135 & Urea-135 & $44.4 \mathrm{a}$ & $7.4 \mathrm{a}$ & $36.3 \mathrm{abc}$ & $269 \mathrm{a}$ \\
\hline Urea & 180 & Urea-180 & $37.5 b$ & $5.7 \mathrm{bc}$ & $39.8 \mathrm{ab}$ & $229 c$ \\
\hline PPB & 45 & РPB-45 & $33.8 \mathrm{bc}$ & $6.5 \mathrm{ab}$ & $32.0 \mathrm{~cd}$ & $208 \mathrm{~cd}$ \\
\hline PPB & 90 & PPB-90 & $33.8 \mathrm{c}$ & $6.0 \mathrm{bc}$ & $28.9 \mathrm{de}$ & $164 \mathrm{ef}$ \\
\hline PPB & 135 & PPB-135 & $31.2 \mathrm{c}$ & $5.9 \mathrm{bc}$ & $27.8 \mathrm{de}$ & $155 \mathrm{f}$ \\
\hline PPB & 180 & PPB-180 & $32.5 \mathrm{c}$ & $6.4 \mathrm{abc}$ & $25.7 \mathrm{e}$ & $163 \mathrm{f}$ \\
\hline$P$-value & & & 0.0021 & 0.0839 & $<0.0001$ & $<0.0001$ \\
\hline
\end{tabular}

${ }^{z}$ means followed by the same letter are not significantly different at $P$-value $=0.10$.

Dry biomass of PPB treated pepper was 5.9 to $6.5 \mathrm{~g} \cdot$ plant $^{-1}$, was not significantly affected by PPB rate and was not generally different than plants that did not receive any N. Similar to our work, Norris et al. (2012) [26] reported that increasing the $\mathrm{PB}$ application rate decreased the dry biomass of perennial ryegrass ( $\mathrm{Lo}$ lium Perrenne L.).

Nitrogen treatment significantly influenced pepper $\mathrm{N}$ concentration $(P<$ 0.0001). The $\mathrm{N}$ concentration of pepper that did not receive any $\mathrm{N}$ was 36.4 $\mathrm{g} \cdot \mathrm{kg}^{-1}$ and that of pepper receiving urea-N or PPB-N were $36.2-40.7$ and 25.7 $32.0 \mathrm{~g} \cdot \mathrm{kg}^{-1}$ respectively. Increasing PPB rate consistently albeit not always significantly lowered the plant $\mathrm{N}$ concentration. This is in agreement with Simmard et al. (1998) [27] who reported that increasing PB application rate decreased $\mathrm{N}$ concentration in barley grain and straw. Similar results were reported by others. Nitrogen concentration of pepper treated with any PPB-N was $13 \%-30 \%$ less than pepper that did not receive any $\mathrm{N}$ and $12 \%-27 \%$ less than plants fertilized with any urea- $\mathrm{N}(P<0.0001)$. The lower pepper $\mathrm{N}$ concentrations are consistent with the general yellowish green color of the PPB amended pepper. Reduction in crop $\mathrm{N}$ concentration in soil amended with $\mathrm{PB}$ has also been reported by others [26] [28].

Pepper $\mathrm{N}$ uptake was significantly $(P<0.0001)$ influenced by $\mathrm{N}$-treatment and reflected the combined effect of $\mathrm{N}$-treatment on plant dry biomass and $\mathrm{N}$ concentration. Nitrogen uptake by pepper that was not fertilized with any $\mathrm{N}$, urea-N, and PPB-N was 194, 229 - 270, and 155 - $164 \mathrm{mg} \cdot$ plant $^{-1}$ respectively. In general urea-N treated pepper removed significantly more $\mathrm{N}$ from soil; pepper fertilized with $180 \mathrm{~kg}$ urea- $\mathrm{N} \mathrm{ha}^{-1}$ was an exception. A similar trend was observed by Gagnon et al. (2012) [2] who noted that $\mathrm{N}$ accumulation by silage corn 
fertilized with $150 \mathrm{~kg}$ inorganic $\mathrm{N} \mathrm{ha}^{-1}$ was significantly more than corn treated with the same amount of total $\mathrm{N}$ from a PB with C:N ratio of 50. Smaller pepper $\mathrm{N}$ uptake at the highest rate of urea- $\mathrm{N}$ is a reflection of smaller plant dry biomass caused by excessive $\mathrm{N}$ supply as evidenced by dark green plant color. In general, pepper treated with urea- $\mathrm{N}$ removed more $\mathrm{N}$ (from the soil) than plants treated with PPB-N. Nitrogen uptake by plants amended with $\geq 90 \mathrm{~kg}$ PPB-N ha ${ }^{-1}$ was significantly less than pepper that did not receive any $\mathrm{N}$. The $\mathrm{N}$ concentration and uptake data indicate that higher rates of PPB resulted in microbial sequestration of the native soil and PPB-N due to its high organic $\mathrm{C}$ content. This is supported by the relatively wide $\mathrm{C}: \mathrm{N}$ ratio (27.2) and very low inorganic $\mathrm{N}$ content of our PPB. Nitrogen immobilization has been reported when PB with C:N ratio $>30$ was applied to soil by others [26] [27] [28]. Other researchers, have noted $\mathrm{N}$ immobilization at C:N ratio of 12 - 30 [12] [13] [29]. Our data indicates that for this particular PPB, N immobilization occurred at the C:N of 27.2. From a beneficial use perspective, $\mathrm{N}$ immobilization, caused by wide C:N ratio of an organic byproduct, can be mitigated by co-application of inorganic $\mathrm{N}$ [30] [31] or incorporation of inorganic $\mathrm{N}$ into the pellets Zerbath et al. (2005) [32], Pawlett et al. (2015) [33], Smith et al. (2015) [34], and Antille et al. (2014) [35].

\section{Post-Harvest Soil Samples}

Soil $\mathrm{pH}, \mathrm{SOM}$, total $\mathrm{C}, \mathrm{N}, \mathrm{NH}_{4}-\mathrm{N}$, and $\mathrm{NO}_{3}-\mathrm{N}$ were significantly influenced by $\mathrm{N}$ treatment $(P>0.1$, Table 5$)$. Soil organic matter and total $\mathrm{C}$ in post-harvest soil samples ranged $17.4-19.4$ and $21.9-35.0 \mathrm{~g} \cdot \mathrm{kg}^{-1}$ respectively. Application of $180 \mathrm{~kg}$ PPB-N ha ${ }^{-1}$ produced significantly more SOM than the other treatments and total $\mathrm{C}$ in soil treated with any $180 \mathrm{~kg} \mathrm{~N} \mathrm{ha}^{-1}$ was significantly more than all other treatments. This confirms that PPB is a good source of $\mathrm{C}$ and organic matter similar to the other types of bulk PB investigated by other researchers [2] [5] [15], Manirakiza et al. (2019) [36], Foley et al. (2002) [37], and N'Dayegamiye et al. (2003) [38]. The observed increase in SOM and total C brought about by $\mathrm{PPB}$, points to the potential soil health benefits of $\mathrm{PPB}$, provided that its $\mathrm{C}: \mathrm{N}$ ratio can be reduced to control microbial sequestration of $\mathrm{N}$. The concentration of $\mathrm{NH}_{4}-\mathrm{N}$ was low $\left(0.11\right.$ to $\left.1.63 \mathrm{mg} \cdot \mathrm{kg}^{-1}\right)$ and in general decreased with increasing

Table 5. Effect of urea and pelleted papermill biosolids (PPB), each applied at two total $\mathrm{N}$ rates on selected chemical properties of the soil samples taken from experimental pots after pepper harvest for a greenhouse study conducted at the University of Arkansas Northeast Research and Extension Center in Keiser, Arkansas in 2017.

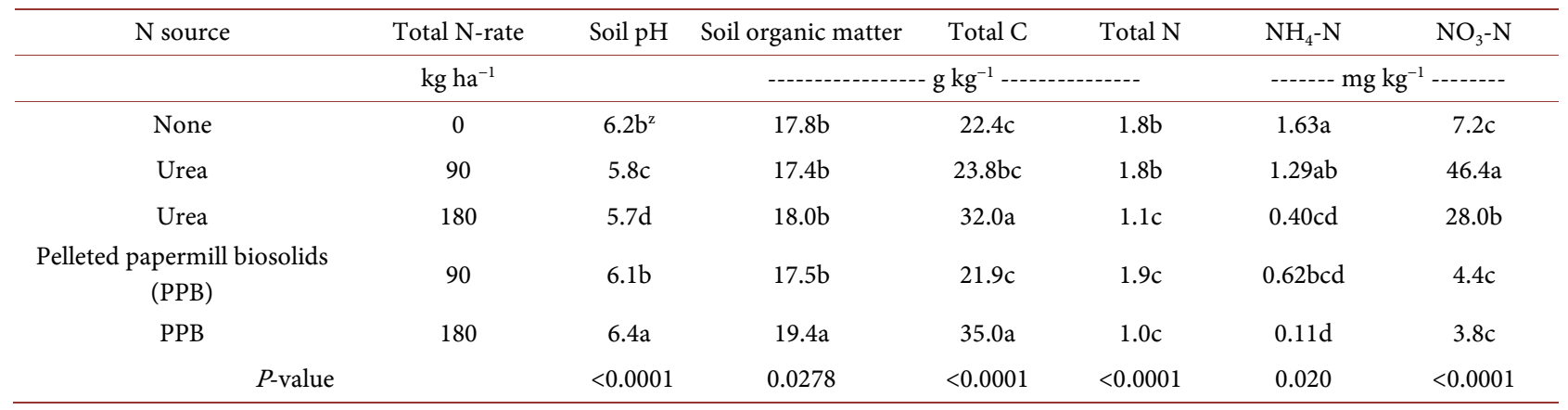

${ }^{z}$ means followed by the same letter are not significantly different at $P$-value $=0.10$. 
$\mathrm{N}$ application rate. Total $\mathrm{N}$ in post-harvest soil samples ranged $1.0-1.9 \mathrm{~g} \cdot \mathrm{kg}^{-1}$, the highest and lowest total $\mathrm{N}$ were observed in soil that did not receive any $\mathrm{N}$ and soil treated with $180 \mathrm{~kg}$ PPB-N ha ${ }^{-1}$ respectively.

The $\mathrm{pH}$ of the soil that did not receive any $\mathrm{N}$ (control) was 6.2, and that of the soils treated with urea or PPB were $5.7-5.8$ and $6.1-6.4$ respectively. The lower $\mathrm{pH}$ of the urea-N treated soil, as compared to control, is attributed to hydrolysis of urea- $\mathrm{N}$ to $\mathrm{NH}_{4}$ and its subsequent conversion to $\mathrm{NO}_{3}-\mathrm{N}$ (nitrification). This is supported by the significantly lower concentration of $\mathrm{NO}_{3}-\mathrm{N}\left(7.2 \mathrm{mg} \cdot \mathrm{kg}^{-1}\right)$ in the control soil as compared to urea-N treated soils (28 - $46 \mathrm{mg} \cdot \mathrm{kg}^{-1}$, Table 5). It is well established that conversion of one mole $\mathrm{NH}_{4}$ to $\mathrm{NO}_{3}$ releases five $\mathrm{H}$ ions. Hydrogen ion secretion by plant roots during nutrient uptake may have also contributed to reducing the soil $\mathrm{pH}$. Acidifying effect of mineral fertilizers has also been reported in similar experiments Vagstad et al. (2001) [7]. In contrast to that, application of high rate of PPB-N significantly increased the soil $\mathrm{pH}$ by 0.2 units. This is consistent with Nunes et al. (2008) [10], who noted that application of $40 \mathrm{Mg} \mathrm{ha}^{-1}$ of PB increased the $\mathrm{pH}$ of two soils by 1 and 1.6 units. Similar results had been reported Cabral et al. (1993) [11]. The numerical decrease in post-harvest soil $\mathrm{NO}_{3}-\mathrm{N}$ had been observed by Douglas et al. (2003) [28].

\section{Concluding Remarks}

Our greenhouse study established that this newly developed PPB is an excellent source of organic matter that will improve the soil health and enhance $C$ sequestration. It also contains some $\mathrm{P}$. The $\mathrm{C}: \mathrm{N}$ ratio of this PPB should be reduced to make it an attractive source of organic $\mathrm{N}$ for a pepper crop. Future research to determine the optimal rate of supplemental $\mathrm{N}$ that should be co-applied or incorporated into this PPB will enhance its widespread use as a beneficial soil amendment.

\section{Conflicts of Interest}

The authors declare no conflicts of interest regarding the publication of this paper.

\section{References}

[1] National Academic Press (1999) Industrial and Environmental Performance Metrics: Challenges and Opportunities. Chapter 7: The Pulp and Paper Industry. https://www.nap.edu/read/9458/chapter/9

[2] Gagnon, B., Ziadi, N., Chantigny, M.H., Bèlanger, G. and Massè, D.I. (2012) Biosolids from Treated Swine Manure and Papermill Residues Affect Corn Fertilizer Value. Agronomy Journal, 104, 483-492. https://doi.org/10.2134/agronj2011.0327

[3] Camberato, J.J., Vance, E.D. and Someshwar, A.V. (1997) Composition and Land Application of Paper Manufacturing Residuals. In: Rechcigl, J.E. and MacKinnon, H.C., Eds., Agricultural Uses of By-Products and Wastes, American Chemical Society Symposium Series 668, Washington DC, 185-202. https://doi.org/10.1021/bk-1997-0668.ch012 
[4] Camberato, J.J., Gagnon, B., Angers, D.A., Chantigny, M.H. and Pan, W.L. (2006) Pulp and Paper Mill By-Products as Soil Amendments and Plant Nutrient Sources. Canadian Journal of Soil Science, 86, 641-653. https://doi.org/10.4141/S05-120

[5] Price, G.W. and Voroney, R.P. (2007) Papermill Biosolids Effect on Soil Physical and Chemical Properties. Journal of Environmental Quality, 36, 1704-1714. https://doi.org/10.2134/jeq2007.0043

[6] Aitken, M.N., Evans, B. and Lewis, J.G. (1998) Effect of Applying Papermill Sludge to Arable Land on Soil Fertility and Crop Yields. Soil Use and Management, 14, 215-222. https://doi.org/10.1111/j.1475-2743.1998.tb00153.x

[7] Vagstad, N., Vagstad, N., Broch-Due, A. and Lyngstad, I. (2001) Direct and Residual Effects of Pulp and Paper Mill Sludge on Crop Yield and Soil Mineral N. Soil Use and Management, 17, 173-178. https://doi.org/10.1079/SUM200172

[8] Ziadi, N., Gagnon, B. and Nyiraneza, J. (2013) Crop Yield and Soil Fertility as Affected by Papermill Biosolids and Liming Byproducts. Canadian Journal of Soil Science, 93, 319-328. https://doi.org/10.4141/cjss2012-129

[9] San Martin, V.B., Undurraga, P., Quezada, C., Celis, J.E. and Sandoval, M.A. (2016) Effect of Pellets Made of Waste Materials from the Paper Industry Enhanced with Seaweed (Ulva lactuca L.) on N Mineralization and Lettuce Production. Chilean Journal of Agricultural Research, 76, 363-370. https://doi.org/10.4067/S0718-58392016000300015

[10] Nunes, J.R., Cabral, F. and Lòpez-Piñeiro, F.A. (2008) Short Term Effects on Soil Properties and Wheat Production from Secondary Paper Sludge Application on Two Mediterranean Agricultural Soils. Bioresource Technology, 99, 935-4942. https://doi.org/10.1016/j.biortech.2007.09.016

[11] Cabral, F. and Vasconcelos, E. (1993) Agricultural Use of Combined Primary/Secondary Pulpmill Sludge. Agrochimica, 37, 409-417.

[12] Cordovil, C., Cabral, F. and Coutinho, J. (2007) Potential Mineralization of Nitrogen from Organic Wastes to Ryegrass and Wheat Crops. Bioresource Technology, 98, 3265-3268. https://doi.org/10.1016/j.biortech.2006.07.014

[13] Sims, J.T. (1990) Nitrogen Mineralization and Elemental Availability in Soils Amended with Cocomposted Sewage Sludge. Journal of Environmental Quality, 19, 669-675. https://doi.org/10.2134/jeq1990.00472425001900040007x

[14] Levy, J.S. and Taylor, B.R. (2003) Effects of Pulpmill Solids and Three Composts on Early Growth of Tomatoes. Bioresource Technology, 89, 297-305. https://doi.org/10.1016/S0960-8524(03)00065-8

[15] Battaglia, A., Calaces, N., Nardi, E., Petronio, B. and Pietrotti, M. (2007) Reduction of $\mathrm{Pb}$ and $\mathrm{Zn}$ Bioavailable Forms in Metal Polluted Soils Due to Papermill Sludge Addition. Effects on $\mathrm{Pb}$ and $\mathrm{Zn}$ Transferability to Barley. Bioresource Technology, 98, 2293-2999. https://doi.org/10.1016/j.biortech.2006.10.007

[16] Huluka, G. and Miller, R. (2014) Particle Size Determination by Hydrometer Method. In: Sikora, F.J. and Moore, K.P., Eds., Soil Test Methods from the Southeastern United States, Southern Coop. Ser. Bull. 419, University of Georgia, Athens, 48-53. http://aesl.ces.uga.edu/sera6/PUB/MethodsManualFinalSERA6.asp

[17] Sikora, F. and Kissel, D. (2014) Soil pH. In: Sikora, F.J. and Moore, K.P., Eds., Soil Test Methods from the Southeastern United States, Southern Coop. Ser. Bull. 419, University of Georgia, Athens, 48-53. http://aesl.ces.uga.edu/sera6/PUB/MethodsManualFinalSERA6.asp

[18] Zhang, H. and Wang, J.J. (2014) Loss on Ignition. In: Sikora, F.J. and Moore, K.P., Eds., Soil Test Methods from the Southeastern United States, Southern Coop. Ser. 
Bull. 419, University of Georgia, Athens, 155-157. http://aesl.ces.uga.edu/sera6/PUB/MethodsManualFinalSERA6.asp

[19] Provin, T. (2014) Total Carbon and Organic Carbon via Thermal Combustion Analyses. In: Sikora, F.J. and Moore, K.P., Eds., Soil Test Methods from the Southeastern United States, Southern Coop. Ser. Bull. 419, University of Georgia, Athens, 149-154.

http://aesl.ces.uga.edu/sera6/PUB/MethodsManualFinalSERA6.asp https://www.nrcs.usda.gov/Internet/FSE_DOCUMENTS/nrcs143_022325.pdf

[20] Miller, R. and Sonon, L. (2014) Nitrate-Nitrogen. In: Sikora, F.J. and Moore, K.P., Eds., Soil Test Methods from the Southeastern United States, Southern Coop. Ser. Bull. 419, University of Georgia, Athens, 136-145. http://aesl.ces.uga.edu/sera6/PUB/MethodsManualFinalSERA6.asp

[21] Zhang, H., Hardy, D.H., Mylavarapu, R. and Wang, J.J. (2014) Mehlich-3. In: Sikora, F.J. and Moore, K.P., Eds., Soil Test Methods from the Southeastern United States, Southern Coop. Ser. Bull. 419, University of Georgia, Athens, 101-110. http://aesl.ces.uga.edu/sera6/PUB/MethodsManualFinalSERA6.asp

[22] Peters, J.B. (2003) Recommended Methods of Manure Analysis. https://www.nrcs.usda.gov/Internet/FSE_DOCUMENTS/nrcs143_022325.pdf

[23] Feagley, S.E., Valdez, M.S. and Hundall, W.H. (1994) Bleached, Primary Papermill Sludge Effect on Bermudagrass Grown on a Mine Soil. Soil Science, 157, 389-397. https://doi.org/10.1097/00010694-199406000-00008

[24] Simard, R.R. (2001) Combined Primary/Secondary Papermill Sludge as a Nitrogen Source in a Cabbage-Sweet Corn Cropping Sequence. Canadian Journal of Soil Science, 81, 1-10. https://doi.org/10.4141/S00-026

[25] Sudha, S. and Pitchai, G.J. (2016) Effect of Waste with Different Levels of Nitrogen on Nutrient Uptake and Yield of Maize, Zea mays. International Journal of Farm Sciences, 6, 7-12.

[26] Norris, M. and Titshall, L. (2010) The Potential for Direct Application of Papermill Sludge to Land: A Greenhouse Study. Proceedings of the 19th World Congress of Soil Science, Brisbane, 1-6 August 2010, 217-220.

[27] Simard, R.R., Baziramakenga, R.S., Yelle, S. and Coulombe, J. (1998) Effects of De-Inking Paper Sludges on Soil Properties and Crop Yields. Canadian Journal of Soil Science, 788, 689-697. https://doi.org/10.4141/S98-003

[28] Douglas, J.T., Aitken, M.N. and Smith, C.A. (2003) Effects of Five Non-Agricultural Organic Wastes on Soil Composition and on the Yield and Nitrogen Recovery of Italian Ryegrass. Soil Use and Management, 19, 135-138.

https://doi.org/10.1079/SUM2003180

[29] Gutser, R., Ebertseder, Th., Weber, A., Schraml, M. and Schmidhalter, U. (2005) Short-Term and Residual Availability of Nitrogen after Long-Term Application of Organic Fertilizers or Arable Land. Journal of Plant Nutrition, 168, 439-446. https://doi.org/10.1002/jpln.200520510

[30] Price, G.W., Voroney, R.P. and Chong, C. (2009) Crop Performance on Soils Receiving Annual Papermill Biosolid Amendments with and without Supplementary Nitrogen. Canadian Journal of Soil Science, 89, 269-279. https://doi.org/10.4141/CJSS08014

[31] Cordovil, C.M.D.S., Cabral, F., Coutinho, J. and Goss, M.J. (2006) Nitrogen Uptake by Ryegrass from Organic Wastes Applied to a Sandy Loam Soil. Soil Use and Management, 22, 320-322. https://doi.org/10.1111/j.1475-2743.2006.00031.x

[32] Zebarth, B.J., Chabot, J., Coulombe, J., Simard, R.R., Douheret, J. and Tremblay, N. 
(2005) Pelletized Organo-Mineral Fertilizer Product as a Nitrogen Source for Potato Production. Canadian Journal of Soil Science, 85, 387-395.

https://doi.org/10.4141/S04-071

[33] Pawlett, M., Deeks, L. and Sakrabani, R. (2015) Nutrient Potential of Biosolids and Urea Derived Organo-Mineral Fertilisers in a Field Scale Experiment Using Ryegrass (Lolium perenne L.). Field Crops Research, 175, 56-63. https://doi.org/10.1016/j.fcr.2015.02.006

[34] Smith, G., Chaney, K., Murray, C. and Le, M. (2015) The Effect of Organo-Mineral Fertilizer Applications on the Yield of Winter Wheat, Spring Barley, Forage Maize and Grass Cut for Silage. Journal of Environmental Protection, 6, 103-109. https://doi.org/10.4236/jep.2015.62012

[35] Antille, D.L., Sakrabani, R. and Godwin, R.J. (2014) Effects of Biosolids-Derived Organo-Mineral Fertilizers, Urea and Biosolids Granules on Crop and Soil Established with Ryegrass (Lolium perenne L.). Communications in Soil Science and Plant Analysis, 45, 1605-1621. https://doi.org/10.1080/00103624.2013.875205

[36] Manirakiza, E., Ziadi, N., St. Luce, M., Hamel, C. and Antoun, H. (2019) Nitrogen Mineralization and Microbial Biomass Carbon and Nitrogen in Response to Co-Application of Biochar and Paper Mill Biosolids. Applied Soil Ecology, 142, 90-98. https://doi.org/10.1016/j.apsoil.2019.04.025

[37] Foley, B.J. and Cooperband, L.R. (2002) Paper Mill Residuals and Compost Effects on Soil Carbon and Physical Properties. Journal of Environmental Quality, 31, 2086-2095. https://doi.org/10.2134/jeq2002.2086

[38] N'Dayegamiye, A., Haurd, S. and Thibault, Y. (2003) Influence of Paper Mill Sludge on Corn Yields and N Recovery. Canadian Journal of Soil Science, 83, 497-450. https://doi.org/10.4141/S02-077

\section{List of Abbreviations}

g: gram.

mg: milligram.

kg: kilogram.

PPB: pelletized papermill biosolids.

SOM: soil organic matter. 